Research paper submitted to "Fuel Processing Technology"

\title{
Novel Fluidized Bed Dryer for Biomass Drying
}

\author{
Yuping Liu ${ }^{\text {a }}$, Jianghong Peng ${ }^{\mathrm{b}}$, Yasuki Kansha ${ }^{\mathrm{a}}$, Masanori Ishizuka ${ }^{\mathrm{a}}$, \\ Atsushi Tsutsumi ${ }^{\text {a, } * \text {, Dening Jia }}{ }^{\text {b }}$, Xiaotao T. Bi ${ }^{b}$, C. J. Lim ${ }^{b}$, Shahab Sokhansanj ${ }^{\text {b,c }}$ \\ ${ }^{a}$ Collaborative Research Center for Energy Engineering, Institute of Industrial Science, \\ The University of Tokyo, 4-6-1 Komaba, Meguro-ku, Tokyo 153-8505, Japan \\ ${ }^{\mathrm{b}}$ Department Chemical and Biological Engineering, University of British Columbia, \\ Vancouver V6T 1Z3, Canada \\ ${ }^{\mathrm{c}}$ Environmental Sciences Division, Oak Ridge National Laboratory, Oak Ridge, TN \\ 37831, USA
}

*Corresponding Author. Tel.: +81-3-5452-6727. Fax: +81-3-5452-6728.

E-mail: a-tsu2mi@iis.u-tokyo.ac.jp. 


\begin{abstract}
Biomass drying is performed mainly in rotary dryers, which occupy a large footprint. To explore the efficient drying of biomass, a fluidized bed dryer was proposed. Good circulation of biomass particles could be established in the fluidized bed without the use of inert particle or mechanical aids. The initial moisture content of the input sawdust affected its fluidization performance. For the drying of sawdust of high-moisture content, the fluidization behavior could be divided into three stages: partial fluidization, full fluidization with increasing drying rate, and full fluidization with decreasing drying rate. A high drying rate could be achieved because of the fast mass and heat transfer rate in the fluidized bed. The fluidized bed dryer has a drying performance similar to the binary mixture fluidized bed dryer but more compact, and requires no separation of dried biomass particles from the inert bed particles.
\end{abstract}




\section{Introduction}

Biomass is a renewable primary energy source because of its low net carbon dioxide emissions. It may be sustainable if its economic, environmental, and social impacts are properly managed. Biomass shows great potential as a sustainable feedstock source for combustion and co-combustion with coal, syngas production by gasification, bio-oil production by pyrolysis, solid formation by carbonization and bioethanol production by fermentation [1-3]. Biomass has a low energy density compared with traditional fossil fuels. This is mainly because of its high moisture content, which commonly exceeds 50 $\mathrm{wt} \%$ (wet basis, wb). This moisture content limits its application as an alternate fuel because of the resultant high transportation costs, storage difficulties and reduced thermal efficiency during energy conversion. Biomass moisture content should be decreased to $8-10 \mathrm{wt} \%(\mathrm{wb})$ prior to densification and energy conversion for economic use [4]. Hence, biomass drying is used to increase the energy density so as to deliver the bulk and widespread biomass to bioconversion plants.

Many kinds of drying systems have been developed for biomass drying such as the conveyor dryers, rotary dryer of single or multiple passes, and the fixed and moving bed dryers, among which rotary dryers are the most common [5-8]. However, because of their operating conditions, horizontal configuration, and low-heat transfer rate, existing biomass dryers are usually large and occupy a large footprint [9]. To improve the economy of biomass-based processes prior to transport, it is desirable to have a compact and economical dryer. Fluidized beds have a high heat transfer rate and exhibit excellent solid mixing and uniform temperature distribution [10]. The fluidized bed dryer could thus be a potential compact dryer for biomass drying. Unfortunately, one of the challenges for biomass drying in fluidized beds is to achieve good gas-solid contact and 
bed stability. Because of their peculiar shape and low density, biomass particles are subject to extensive channeling and slugging and cannot be fluidized properly in normal fluidized beds even at high gas velocities [11-13]. An inert material such as silica sand, glass spheres, alumina, or calcite is usually used to facilitate fluidization of the biomass particles, which are present only in a small fraction [14]. The introduction of inert particles into the fluidized bed may contaminate the dried biomass product and increase the pressure drop through the bed. Mechanically assisted fluidized beds such as vibrated or agitated and pulsed fluidized beds have been used for biomass drying without the addition of inert particles $[15,16]$. However, the increased equipment complexity may result in operational problems and increase the cost of the device. Biomass could also be dried in spouted beds at high gas velocities [17]; however, the heat transfer rate decreases because of the inefficient gas-solid contact compared with fluidized beds [18].

The aim of this work is to explore a compact and economical dryer for biomass drying by using the advantages of high mass and heat transfer rates in the fluidized bed. A new fluidized bed dryer was proposed for biomass drying with inclined micro-jet distributor design. During drying, the fluidization behavior of the pure biomass particles would be affected by evaporating and wet regions on the surface of the particles and the inter-particle capillary forces. In addition, during the drying process, the fluidization behavior may be altered as the moisture content decreasing. Thus, the fluidization performance needs to be examined during the drying process. The biomass drying rate also had to be investigated to confirm the drying performance in the proposed fluidized bed dryer. In this work, the effects of air velocity and drying temperature were investigated to evaluate the performance of the fluidized bed dryer.

\section{Materials and methods}




\subsection{Materials and experimental equipment}

The sawdust sample, obtained from RONA lumber store in Vancouver, Canada, is a mixture of spruce and fir, with spruce as the main component. The sample was separated into two size fractions of $250-355$ and $355-500 \mu \mathrm{m}$, respectively, using a Ro-Tap RX94 sieving device (W.S. TYLER Co. Ohio, USA). The solid density of the sawdust measured using a multi-pycnometer (Quantachrome Instruments Co. Florida, USA) was $1388 \mathrm{~kg} \mathrm{~m}^{-3}$. The bulk density of wet sawdust with $60 \mathrm{wt} \%$ (wb) moisture content was $282 \mathrm{~kg} \mathrm{~m}^{-3}$.

Batch runs for drying the sawdust were conducted in a stainless steel fluidized bed dryer, $1.5 \mathrm{~m}$ tall and $50 \mathrm{~mm}$ in diameter, as shown in Fig. 1a. A gas distributor with $30^{\circ}$ vertically inclined orifices was designed to achieve a good solid circulation. Twelve holes were located around the peripheral region and two holes in the center with an inclined angle opposite the outer region. As a result, a solid circulation pattern was established with sawdust particles rising in the center, passing through a fountain region and then moving down slowly along the wall. This kept the entire bed of particles in motion as shown in Fig. 1b. Three thermocouples (T1, T2, and T3) were used to measure the temperatures of the inlet gas, fluidized bed, and reactor wall and control the electric heater by means of a proportional integral derivative controller. The pressure drop across the fluidized bed was measured by the pressure difference between the pressure transducer P1 before and after the sawdust input. Dry air from an air cylinder was preheated to the desired temperature before being fed into the fluidized bed. The air flow was measured using a rotameter. As the drying progressed, water in the sample evaporated into the air. A hygrometer (HUMICAP, Vaisala, Finland, with precision of $1.0 \%$ ) was installed at the fluidized bed dryer outlet to monitor the relative humidity 
and temperature of the humid air simultaneously. The wall surface of the fluidized bed dryer was maintained at a certain temperature by an electric heater surrounding the outer wall of the fluidized bed. The reactor was insulated to prevent heat loss from the bed to the environment.

\subsection{Experimental procedure}

The fluidized bed dryer was heated slowly to the targeted drying temperature and kept stable for at least $10 \mathrm{~min}$. Wet sawdust of a particular moisture content was weighed using a balance with precision of $0.1 \mathrm{mg}$ and fed from the top of the fluidized bed. The sawdust was fluidized by air with a predetermined flow over a desired residence time period. During the drying process, water was transferred from the wet sawdust to the air. Since it was difficult to investigate the mass change of the sawdust in the stainless steel fluidized bed during the drying process, the mass loss of wet sawdust, $W_{\text {loss, }}$, was calculated from the amount of water carried out by the air.

$$
\left.W_{\text {loss }}=w_{\mathrm{n}}-w_{\mathrm{m}}=m_{\mathrm{g}} \sum_{\mathrm{i}=\mathrm{m}}^{\mathrm{n}} Y_{\mathrm{i}} \quad \text { [g-water }\right]
$$

where $w_{\mathrm{n}}$ and $w_{\mathrm{m}}$ are the mass of wet sawdust at different times. The drying rate, $R_{\mathrm{w}}$, is determined by Eq. 2:

$$
R_{\mathrm{w}}=\frac{\mathrm{d} w}{\mathrm{~d} t}=\frac{m_{\mathrm{g}} \sum_{\mathrm{i}=\mathrm{m}}^{\mathrm{n}} Y_{\mathrm{i}}}{t_{\mathrm{n}}-t_{\mathrm{m}}}=\frac{m_{\mathrm{g}}\left(Y_{\mathrm{m}}+Y_{\mathrm{m}+1}+\cdots+Y_{\mathrm{i}}\right)}{t_{\mathrm{n}}-t_{\mathrm{m}}} \quad[\mathrm{g} \text {-water } / \mathrm{min}]
$$

where $m_{\mathrm{g}}$ is the amount of air and $Y$ is the specific humidity, which is the ratio of mass of water vapor per unit mass of dry air, as calculated from:

$$
Y=0.622\left(\frac{p_{\mathrm{s}}}{p-p_{\mathrm{s}}}\right) \quad[\mathrm{g} \text {-water } / \mathrm{kg} \text {-air }]
$$


The water vapor saturation pressure was calculated from the Wagner-Pruss equation [19]:

$$
\begin{aligned}
& \ln \left(\frac{\mathrm{p}_{\mathrm{s}}}{22.064 \mathrm{e} 6}\right)=647.096 / \mathrm{T}_{\mathrm{k}}\left(-7.85951783 v+1.84408259 v^{1.5}-11.7866497 v^{3}+22.6807411 v^{3.5}\right. \\
& \left.-15.9618719 v^{4}+1.80122502 v^{7.5}\right)
\end{aligned}
$$

where

$$
v=1-T / 647.096
$$

$T$ is absolute air temperature $(\mathrm{K})$. At the conclusion of the drying cycle, dried samples were collected and their final moisture content, $W_{\text {wet, }}$ was determined according to the ASTM D4442-07 standard by heating the sample at $103^{\circ} \mathrm{C}$ for $24 \mathrm{~h}$ in an oven [20], with the moisture content given by

$W_{\text {wet }}=\frac{M_{1}-M_{2}}{M_{1}} \times 100 \% \quad[\mathrm{wt} \% \mathrm{wb}]$,

where $M_{1}$ is the initial sampled dried sawdust and $M_{2}$ is final weights of the samples after drying in the oven for $24 \mathrm{~h}$ at $103^{\circ} \mathrm{C}$, respectively.

The specific drying rate in the fluidized bed dryer, $R_{\mathrm{sp}}$, was defined as the ratio of drying rate to mass of dried biomass, $M_{\text {dry }}$.

$$
\left.R_{\mathrm{sp}}=\frac{1}{M_{\mathrm{dry}}} \frac{\mathrm{d} w}{\mathrm{~d} t}=\frac{R_{\mathrm{w}}}{M_{\mathrm{dry}}} \quad \text { [g-water/g-biomass } / \mathrm{min}\right]
$$

\section{Results and discussion}

\subsection{Fluidization behavior in fluidized bed dryer}

Biomass has a typical moisture content of over $50 \mathrm{wt} \%(\mathrm{wb})$, which is expected to have a strong effect on the fluidization behavior of biomass particles. We first 
investigated the effect of sawdust moisture content on fluidization performance. The fluidization behavior is assessed from the pressure drop across the fluidized bed, which is believe to be an important indicator [21,22], reflecting changes in the fluidization behavior in the fluidized bed [23]. In this study, we investigated the pressure loss across the fluidized bed through change of pressure drop during the sawdust drying. Drying rates at different operating conditions were also investigated to link the hydrodynamic characteristics to the mechanisms of drying. The change in drying rate could reflect the fluidization conditions in the fluidized bed indirectly because the drying rate was high under good fluidization conditions. Prior to drying, the minimum fluidization velocities of dry sawdust of different sizes were determined in a cold model unit, and a velocity of $0.32 \mathrm{~m} \mathrm{~s}^{-1}$ was found to give a stable fluidization of $20 \mathrm{~g}$ sawdust sample.

Fig. 2 shows the drying curves of $20 \mathrm{~g}$ sawdust at an initial moisture content of 60,40 , and $20 \mathrm{wt} \%(\mathrm{wb})$. Three different water contents of sawdust were chosen to investigate the effect of moisture content on fluidization behavior. To dry sawdust with a moisture content of $60 \mathrm{wt} \%(\mathrm{wb})$, pressure drop P1 was approximately at $4 \mathrm{kPa}$ initially and increased to $10 \mathrm{kPa}$ after 4 min drying when the sawdust moisture content dropped to $50.1 \mathrm{wt} \%(\mathrm{wb})$. The drying rate increased initially during the preheating period and decreased as the drying progressing. It rose again when the sawdust moisture content further decreased and then decreased until the drying completed. When drying sawdust with a moisture content of 40 and $20 \mathrm{wt} \%$ (wb), the drying rate increased initially during the preheating period and then decreased gradually as the inner moisture was transported to the surface by diffusion. Different from the case with initial moisture content of $60 \mathrm{wt} \%$ (wb), P1 increased initially by 10 and $8 \mathrm{kPa}$, respectively, and then remained almost constant with a decrease of $1-2 \mathrm{kPa}$ once the drying had been 
completed because of the mass loss. Once the moisture content of the sawdust had dropped to less than $40 \mathrm{wt} \%$ (wb), the wet sawdust could be fully fluidized. The low initial moisture content of the input sawdust allowed it to reach full fluidization because of the weak capillary forces between the biomass particles.

The effect of bed height to diameter (H/D) ratio on the fluidization performance was investigated next. Fig. 3 a shows the drying rate at different $\mathrm{H} / \mathrm{D}$ values of $0.5,1.0$, and 2.0 with sawdust loadings of 10,20 , and 30 g, respectively. In the initial drying period, water evaporated from the biomass surface and a fast drying rate was achieved in all cases. With the decrease in surface water ratio, the drying rate began to decrease. For $\mathrm{H} / \mathrm{D}$ values of 1.0 and 2.0, the drying rate rose again at similar moisture contents of 50.1 and $51.7 \mathrm{wt} \%(\mathrm{wb})$, respectively, likely due to the improved fluidization quality. With further surface water removal, the internal diffusion rate controlled the drying process, causing the drying rate to drop again at a moisture content of 43.5 and $42.5 \mathrm{wt} \%(\mathrm{wb})$, respectively. For an $\mathrm{H} / \mathrm{D}$ value of 0.5 , the stable fluidization was achieved initially for the small loading of sawdust. A small trough was found after the peak in the drying curve which was suspected to correspond to the onset of full fluidization following partial fluidization. Water in the sawdust occurs in three forms as surface, capillary, and bound water. Surface water on the biomass surface has the same properties as free liquid water. Capillary water in the cell cavities is more difficult to evaporate because of the strong capillary forces. Bound water requires energy to break free from the polymer chains in the cell wall. Fig. $3 \mathrm{~b}$ shows the drying rate as a function of sawdust moisture content and helps explain the relationship between fluidization behavior and sawdust moisture content. The fluidization behavior can be divided into three stages indicated by numbers 1,2 , and 3 on the drying curve. Point 1 is the starting point, point 2 is the 
transition point from partial to full fluidization with increasing drying rate, and point 3 is the transition point from full fluidization with an increasing drying rate to full fluidization with a decreasing drying rate. During partial fluidization (1-2), sawdust particles were partially fluidized, most likely due to the agglomeration of those high moisture content sawdust particles. With progressing drying, part of the surface water was removed and capillary forces between the particles became weakened. Full fluidization with an increasing drying rate (2-3) was reached in which the whole bed became fluidized and the drying rate increased because of the increased mass and heat transfer rates. After the surface water had been removed, full fluidization with a decreasing drying rate (3- ) occurred when internal water diffusion became the limiting factor.

Figs. $4 \mathrm{a}$ and $4 \mathrm{~b}$ show the drying rates as a function of sawdust moisture at various air velocities and bed temperatures. With the exception of the air velocity of $0.14 \mathrm{~m} \mathrm{~s}^{-1}$ in which the packed bed formed, in the other cases, three drying stages existed during the drying process. The moisture content at point 2 was lower when the sawdust was dried at a higher drying temperature or air velocity. The thin liquid film over the particle surface had to be removed to eliminate capillary forces and full fluidization could only occur once the overall particle surface water had been removed. This resulted in a lower moisture content at point 2 , because more water could be removed during the partial fluidization drying period at a higher temperature or gas velocity. This could also lower the moisture content at point 3 for the same reason. A study of the relationship between moisture content and fluidization behavior provides critical information for the stable drying of sawdust particles such as in a continuous fluidized dryer. The moisture content of sawdust in which partial fluidization occurred has been determined. Thus, the 
maximum feeding rate of wet sawdust for continuous operation could also be determined to control the moisture content of the whole bed under the above moisture content to prevent the partial fluidization in the current fluidized bed dryer.

\subsection{Drying kinetics in the fluidized bed dryer}

Results from the drying kinetics in the fluidized bed dryer show that increasing the air velocity from 0.14 to $0.32 \mathrm{~m} \mathrm{~s}^{-1}$ could enhance the drying rate significantly (Fig. 5a). This occurs because a low air velocity would not sufficient to fluidize biomass particles and the bed stayed in a fixed state. When the air velocity increased over $0.32 \mathrm{~m} \mathrm{~s}^{-1}$, stable fluidization resulted. The wall-to-bed heat transfer rate in the fluidized bed was much higher than that of the fixed bed because of bubble-induced bed-material refreshment along the heated wall [24]. As a result, the moisture content of the sawdust could be decreased by $10 \mathrm{wt} \%(\mathrm{wb})$ in the first $3 \mathrm{~min}$ at an air velocity of $0.32 \mathrm{~m} \mathrm{~s}^{-1}$, while it took more than $10 \mathrm{~min}$ at an air velocity of $0.14 \mathrm{~m} \mathrm{~s}^{-1}$. When the air velocity increased to $0.35 \mathrm{~m} \mathrm{~s}^{-1}$, the drying rate increased slightly compared with that at $0.32 \mathrm{~m}$

$\mathrm{s}^{-1}$ because of the increased external mass transfer rate. At the air velocities of 0.32 and $0.35 \mathrm{~m} \mathrm{~s}^{-1}$, the drying rates were both significantly high during the first 6 min when surface water was evaporated. The drying rate then dropped as capillary water was removed. The higher air velocity increases the external water diffusion rate and the drying rate in the constant rate drying period is affected significantly by the velocity of the drying medium compared with the falling rate period. As the air velocity was $0.14 \mathrm{~m}$ $\mathrm{s}^{-1}$, the drying rate decreased gradually because of the decrease in surface water ratio as the drying progressed.

The heat provided for water evaporation comes mainly from the heated wall surface of the fluidized bed while air mainly plays a role as the drying medium. Thus, it is 
important to investigate the effect of bed temperature on drying rate. Fig. $5 \mathrm{~b}$ shows the sawdust drying rate at three temperatures of 75,90 , and $105^{\circ} \mathrm{C}$. A high bed temperature increased the drying rate. This occurs because an increase in bed temperature decreases the relative humidity of the air and increases the mass transfer driving force for water removal from inside the particle. Another important effect of the high bed temperature is to lower the final moisture contents result in the dried sawdust. At high temperature, water molecules become activated to higher energy levels. They become less stable and break away from the water binding sites of the material. This decreases the equilibrium moisture content [25]. The drying rate of sawdust at two size fractions, 250-355 and 355-500 $\mu \mathrm{m}$, was also investigated. The particle size was reported to have an effect on drying rate in both the constant and falling rate drying periods because of a larger specific surface area and shorter diffusion paths for smaller particles. As expected, the drying rate of the $250-355 \mu \mathrm{m}$ sawdust was slightly higher than that of the $355-500 \mu \mathrm{m}$ fraction because of the increased internal and external moisture diffusion. However, the particle size did not have a significant effect on drying rate as shown in Fig. 5c, likely because the overall transfer process is controlled by external diffusion, as observed by other researchers $[17,26]$. Based on these investigations, the drying rate was believed to be affected mainly by air velocity and bed temperature for a given particle size and biomass loading. The initial moisture could affect the initial fluidization quality.

\subsection{Drying of binary mixture particles}

Binary mixture of biomass and sand particles are often used for fluidized bed biomass combustion and gasification. Although drying kinetics of binary mixtures of homogeneous materials have been studied recently, drying kinetics have not been frequently reported on [27]. To evaluate the drying performance of the current fluidized 
bed dryer, we conducted sawdust drying with a sintered metal distributor at the same drying conditions as the newly designed dryer (see Fig. 6a). Silica sand $\left(d_{\mathrm{p}}=0.1 \mathrm{~mm}\right)$ was added to co-fluidize with the sawdust. The mass ratio of wet sawdust to silica sand of the binary mixture in the fluidized bed dryer was $9.0 \mathrm{wt} \%$, which made it easy to fluidize even at the presence of high moisture content sawdust. Sheathed heaters were installed inside the fluidized bed dryer to maintain a constant bed temperature. When the bed temperature reached the desired temperature, sawdust with a moisture content of $63 \mathrm{wt} \%(\mathrm{wb})$ was fed from the top of the dryer. The final moisture content of the dried samples was measured in an oven based on the ASTM D4442-07 standard.

Fig. $6 \mathrm{~b}$ shows the average specific drying rates for drying times of 5 and $15 \mathrm{~min}$. The specific drying rates, $R_{\mathrm{sp}}$, were almost the same in the two drying systems, which illustrates that the two systems had a similar drying rate for the same amount of biomass. In the binary mixture fluidized bed dryer, the input inert particles would enhance the heat transfer rate by filling the space between the biomass particles. In the new fluidized bed dryer, high coefficients of interfacial mass and heat transfer were achieved because of the high gas-solid slip velocity. Table 1 lists the final moisture contents of the dried sawdust in the two drying systems. The final moisture content which was $8.90 \mathrm{wt} \%$ (wb) in the new fluidized bed dryer was almost the same as that in the conventional fluidized bed dryer $(8.88 \mathrm{wt} \%$, wb). However, without inert particle addition, the new fluidized bed dryer had a higher biomass particle density and required no separation of dried sawdust from the sand. This makes the system more compact and economical.

\section{Conclusions}

A newly designed fluidized bed dryer for drying biomass was proposed and evaluated on its hydrodynamic and drying performance. Full fluidization could be established 
right at the beginning for low sawdust moisture contents. For high sawdust moisture contents, the fluidization behavior could be divided into three stages: partial fluidization, full fluidization with an increasing drying rate, and full fluidization with a decreasing drying rate. The current fluidized bed dryer has a high drying rate which is similar to a conventional fluidized bed dryer of a binary mixture, but, more compact and does not require biomass separation from inert particles.

\section{Acknowledgments}

The authors are grateful for the financial support provided by the Japanese-Canadian (JST-NSERC) Research Cooperative Program as part of the FY 2012 Strategic International Research Cooperative Program. The authors also thank Dr. Hui Li from the Hunan Academy of Forestry for his valuable discussion during the paper preparation. 


\section{References}

[1] A. Maciejewska, H. Veringa, J. Sanders and S. D. Peteves, Co-firing of biomass with coal: constraints and role of biomass pre-treatment. http://ie.jrc.ec.europa.eu/publications/scientific_publications/2006/EUR22461EN.p df.

[2] L. Wang, C. L. Weller, D. D. Jones and M. A. Hanna, Contemporary issues in thermal gasification of biomass and its application to electricity and fuel production, Biomass \& Bioenergy 32 (2008) 573-581.

[3] P. McKendry, Energy production from biomass (part 2): conversion technologies, Bioresource Technology 83 (2002) 47-54.

[4] N. Kaliyan and R. V. Morey, Factors affecting strength and durability of densified biomass products, Biomass \& Bioenergy 33 (2009) 337-359.

[5] A. A. Zabaniotou, Simulation of forestry biomass drying in a rotary dryer, Drying Technology 18 (2000) 1415-1431.

[6] S. S. Waje, B. N. Thorat and A. S. Mujumdar, An experimental study of the thermal performance of a screw conveyor dryer, Drying Technology 24 (2006) 293-301.

[7] S. S. Waje, B. N. Thorat and A. S. Mujumdar, Screw conveyor dryer: Process and equipment design, Drying Technology 25 (2007) 241-247.

[8] E. F. Zanoelo, G. M. di Celso and G. Kaskantzis, Drying kinetics of mate leaves in a packed bed dryer, Biosystems Engineering 96 (2007) 487-494.

[9] L. Fagernas, J. Brammer, C. Wilen, M. Lauer and F. Verhoeff, Drying of biomass for second generation synfuel production, Biomass \& Bioenergy 34 (2010) $1267-1277$. 
[10] W. R. W. Daud, Fluidized Bed Dryers - Recent Advances, Advanced Powder Technology 19 (2008) 403-418.

[11] R. Moreno, G. Antolin and A. Reyes, Quality of fluidisation for the drying of forestry Biomass particles in a fluidised bed, Biosystems Engineering 94 (2006) 47-56.

[12] H. P. Cui and J. R. Grace, Fluidization of biomass particles: A review of experimental multiphase flow aspects, Chemical Engineering Science 62 (2007) 45-55.

[13] K. L. Clarke, T. Pugsley and G. A. Hill, Fluidization of moist sawdust in binary particle systems in a gas-solid fluidized bed, Chemical Engineering Science, 60 (2005) 6909-6918.

[14] T. R. Rao and J. V. R. Bheemarasetti, Minimum fluidization velocities of mixtures of biomass and sands, Energy 26 (2001) 633-644.

[15] A. Reyes, R. Vega and G. Garcia, Drying sawdust in a pulsed fluidized bed, Drying Technology 26 (2008) 476-486.

[16] I. Puspasari, M. Z. M. Talib, W. R. W. Daud and S. M. Tasirin, Fluidization characteristics of oil palm frond particles in agitated bed, Chemical Engineering Research \& Design 91 (2013) 497-507.

[17] M. Olazar, G. Lopez, H. Altzibar, M. Amutio and J. Bilbao, Drying of Biomass in a Conical Spouted Bed with Different Types of Internal Devices, Drying Technology 30 (2012) 207-216.

[18] J. Klassen and P. E. Gishler, Heat transfer from column wall to bed in spouted fluidized and packed systems, The Canadian Journal of Chemical Engineering 36 (1958) 12-18. 
[19] W. Wagner and A. Pruss, International Equations for the Saturation Properties of Ordinary Water Substance - Revised According to the International Temperature Scale of 1990 (Vol 16, Pg 893, 1987), Journal of Physical and Chemical Reference Data 22 (1993) 783-787.

[20] ASTM Standard D4442-07, 2003. Standard Test Methods for Direct Moisture Content Measurement of Wood and Wood-Base Materials. ASTM International, West Conshohocken, PA, 2003.

[21] D. Bai, A. S. Issangya and J. R. Grace, Characteristics of gas-fluidized beds in different flow regimes, Industrial \& Engineering Chemistry Research 38 (1999) 803-811.

[22] H. T. Bi, N. Ellis, I. A. Abba and J. R. Grace, A state-of-the-art review of gas-solid turbulent fluidization, Chemical Engineering Science 55 (2000) 4789-4825.

[23] M. Wormsbecker and T. Pugsley, The influence of moisture on the fluidization behaviour of porous pharmaceutical granule, Chemical Engineering Science, 63 (2008) 4063-4069.

[24] J. A. M. Kuipers, W. Prins and W. P. M. Vanswaaij, Numerical-Calculation of Wall-to-Bed Heat-Transfer Coefficients in Gas-Fluidized Beds, AIChE Journal 38 (1992) 1079-1091.

[25] K. B. Palipane and R. H. Driscoll, Moisture Sorption Characteristics of in-Shell Macadamia Nuts, Journal of Food Engineering 18 (1993) 63-76.

[26] A. N. Chandran, S. S. Rao and Y. B. G. Varma, Fluidized-Bed Drying of Solids, AIChE Journal 36 (1990) 29-38.

[27] G. Srinivas and Y. Pydi Setty, Drying behavior of uniform and binary mixture of solids in a batch fluidized bed dryer, Powder Technology 241 (2013) 181-187. 


\section{Figure captions}

Fig. 1a. Schematic of fluidized bed drying unit.

Fig. 1b. Left: solid circulation pattern in new fluidized bed dryer; right: sawdust $(255-500 \mu \mathrm{m})$ fluidization in cold model.

Fig. 2. Effect of initial sawdust moisture content on sawdust drying rate. Bed and air temperature were $90^{\circ} \mathrm{C}$. Air velocity was $0.32 \mathrm{~m} \mathrm{~s}^{-1}$.

Fig. 3a. Sawdust drying rate at different H/D values. Initial moisture content of sawdust was $60 \mathrm{wt} \%(\mathrm{wb})$ and bed and air temperature were $90^{\circ} \mathrm{C}$. Air velocity was $0.32 \mathrm{~m} \mathrm{~s}^{-1}$. Fig. 3b. Sawdust drying rate as a function of moisture content at different H/D values. Initial moisture content of sawdust was $60 \mathrm{wt} \%(\mathrm{wb})$ and bed and air temperature were $90^{\circ} \mathrm{C}$. Air velocity was $0.32 \mathrm{~m} \mathrm{~s}^{-1}$.

Fig. 4a. Effect of air velocity on sawdust fluidization behavior. Initial moisture content of sawdust was $60 \mathrm{wt} \%(\mathrm{wb})$ and bed and air temperature were $90^{\circ} \mathrm{C}$.

Fig. 4b. Effect of bed temperature on sawdust fluidization behavior. Initial moisture content of sawdust was $60 \mathrm{wt} \%$ (wb) and air temperature was $90^{\circ} \mathrm{C}$. Air velocity was $0.32 \mathrm{~m} \mathrm{~s}^{-1}$.

Fig. 5a. Effect of air velocity on sawdust drying rate. Initial moisture content of sawdust was $60 \mathrm{wt} \%(\mathrm{wb})$ and bed and air temperature were $90^{\circ} \mathrm{C}$.

Fig. 5b. Effect of bed temperature on sawdust drying rate. Initial moisture content of sawdust was $60 \mathrm{wt} \%$ (wb). Air temperature was $90^{\circ} \mathrm{C}$ and air velocity was $0.32 \mathrm{~m} \mathrm{~s}^{-1}$. Fig. 5c. Effect of particle diameter on sawdust drying rate. Initial moisture content of sawdust was $60 \mathrm{wt} \%(\mathrm{wb})$. Air temperature was $90^{\circ} \mathrm{C}$ and air velocity was $0.32 \mathrm{~m} \mathrm{~s}^{-1}$. Fig. 6a. Schematic of binary mixture fluidized bed dryer for biomass drying. 
Fig. 6b. Specific drying rates in fluidized bed dryer with binary mixture and newly designed fluidized bed dryer. 
Figure 1a

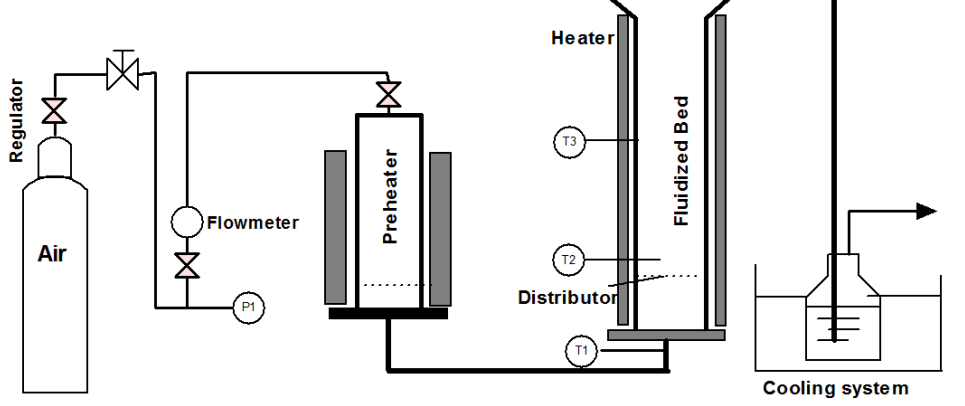


Figure 1b

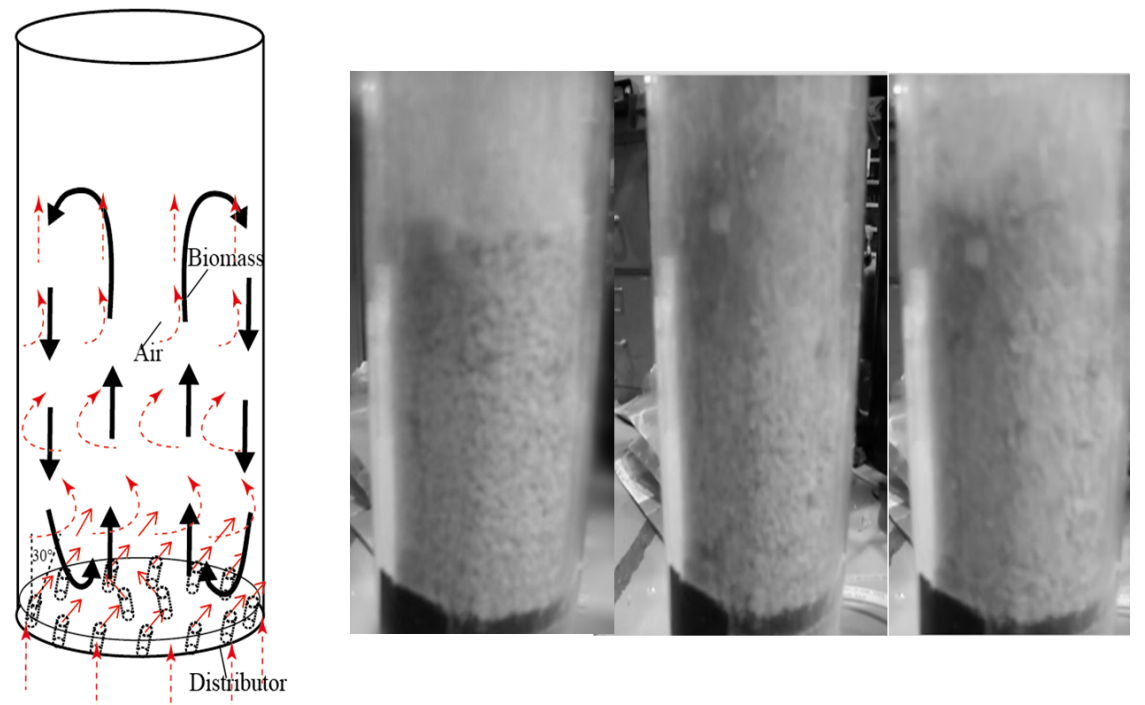


Figure 2

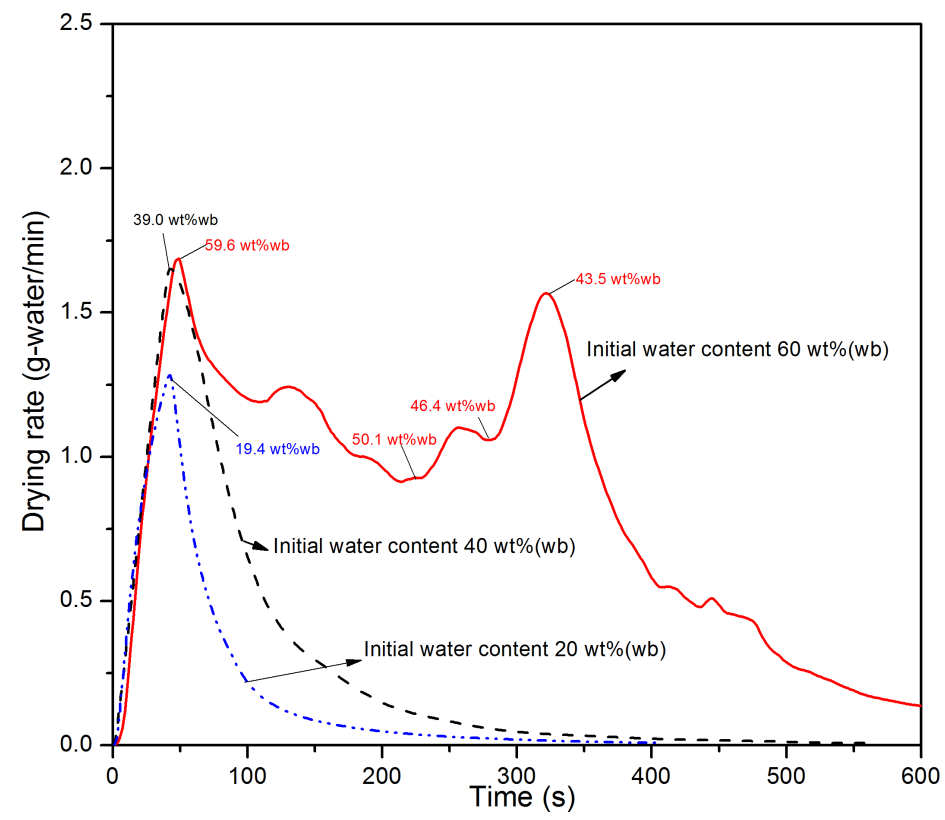


Figure $3 a$

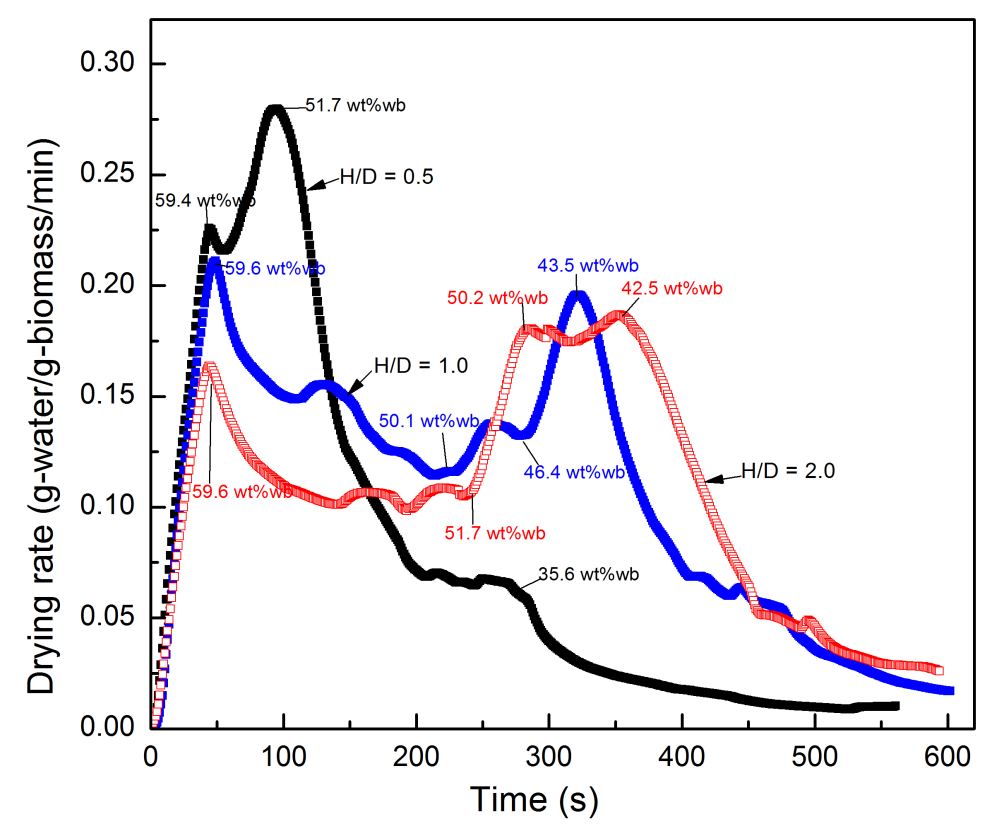


Figure $3 b$

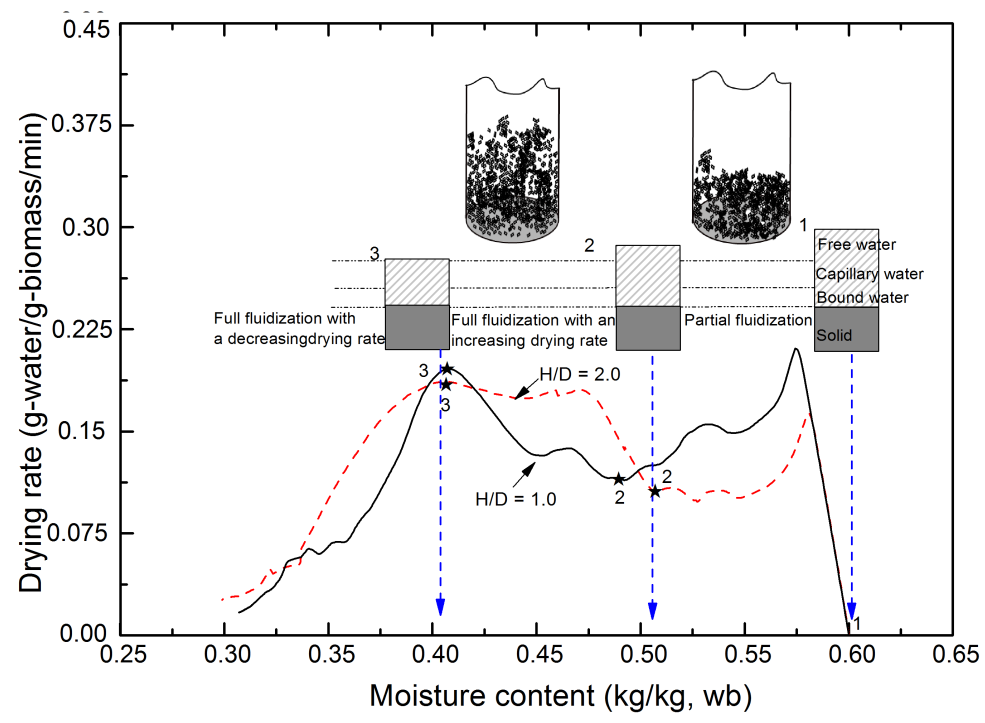


Figure $4 a$

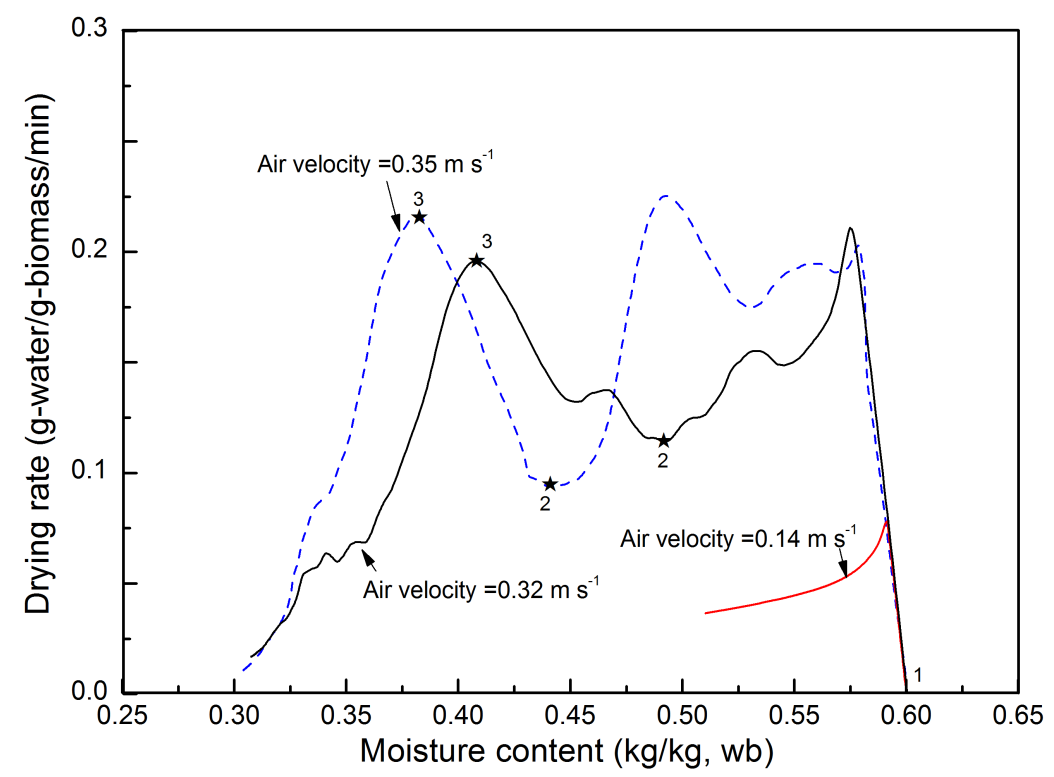


Figure $4 b$

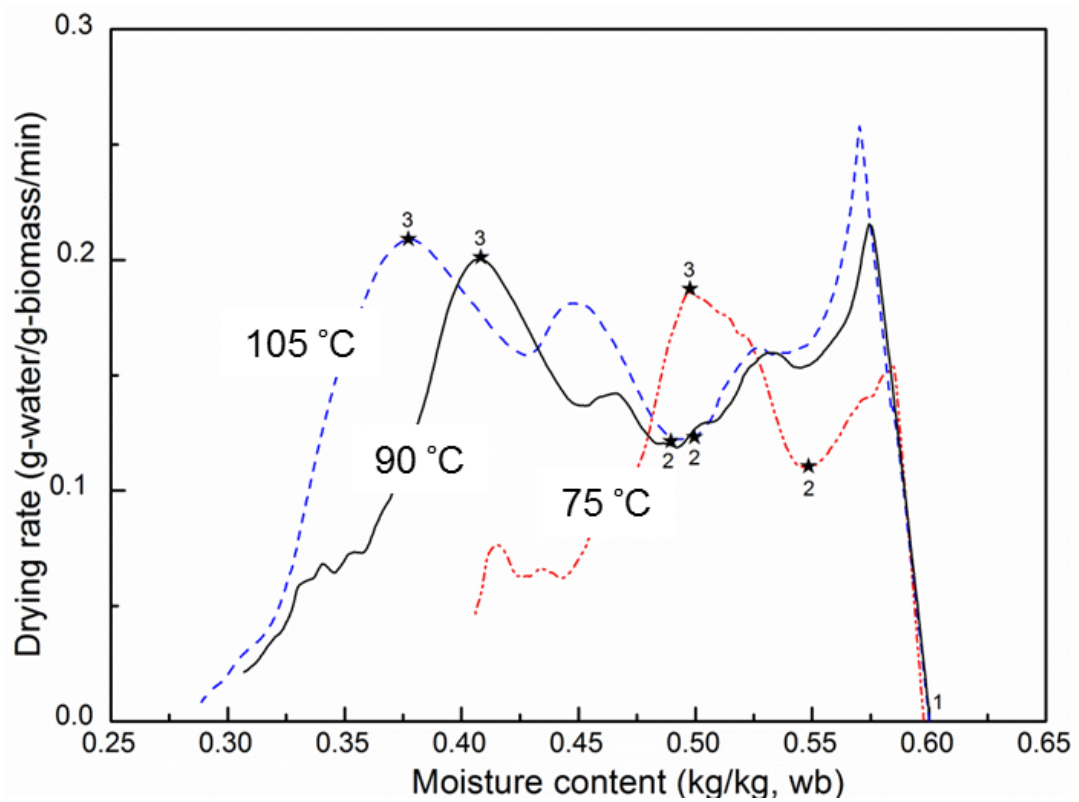


Figure 5a

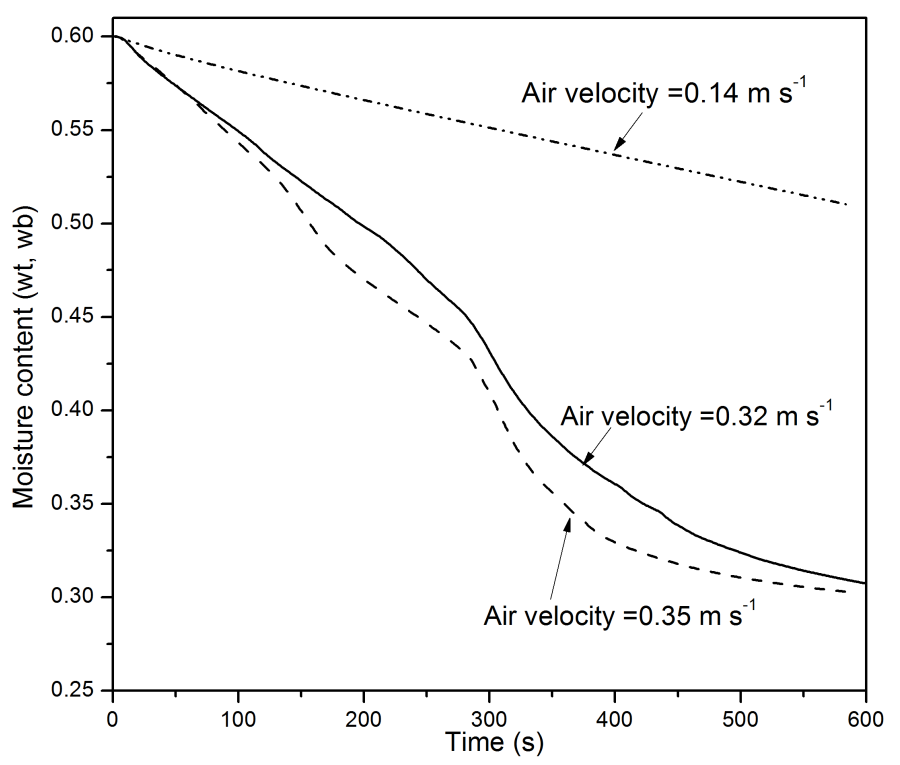


Figure 5b

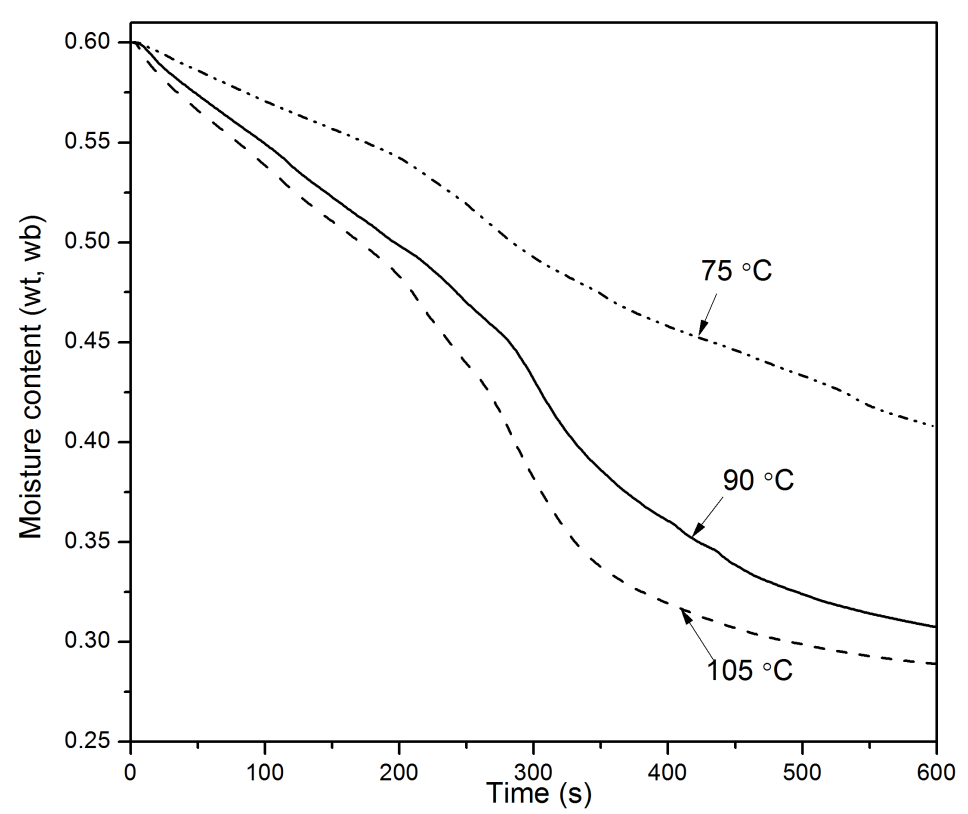


Figure 5c

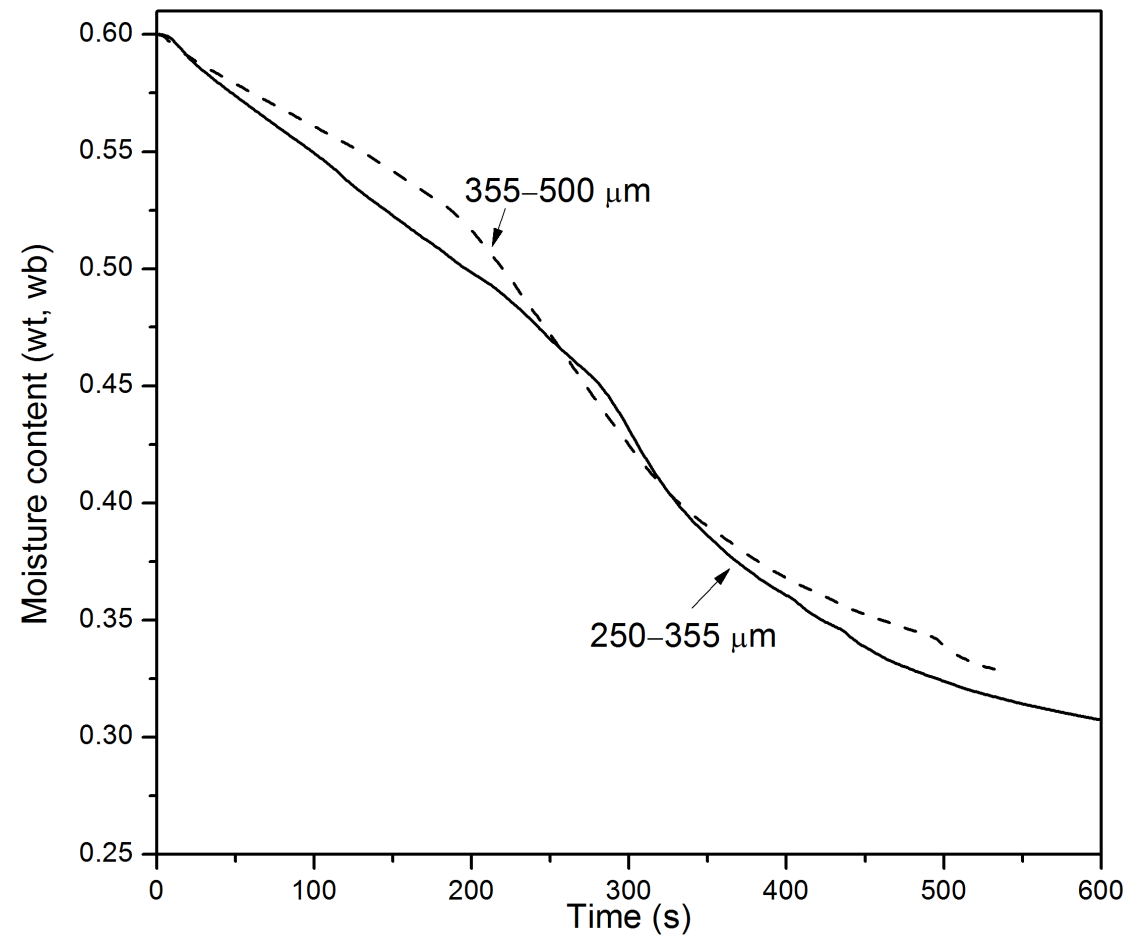


Figure 6a

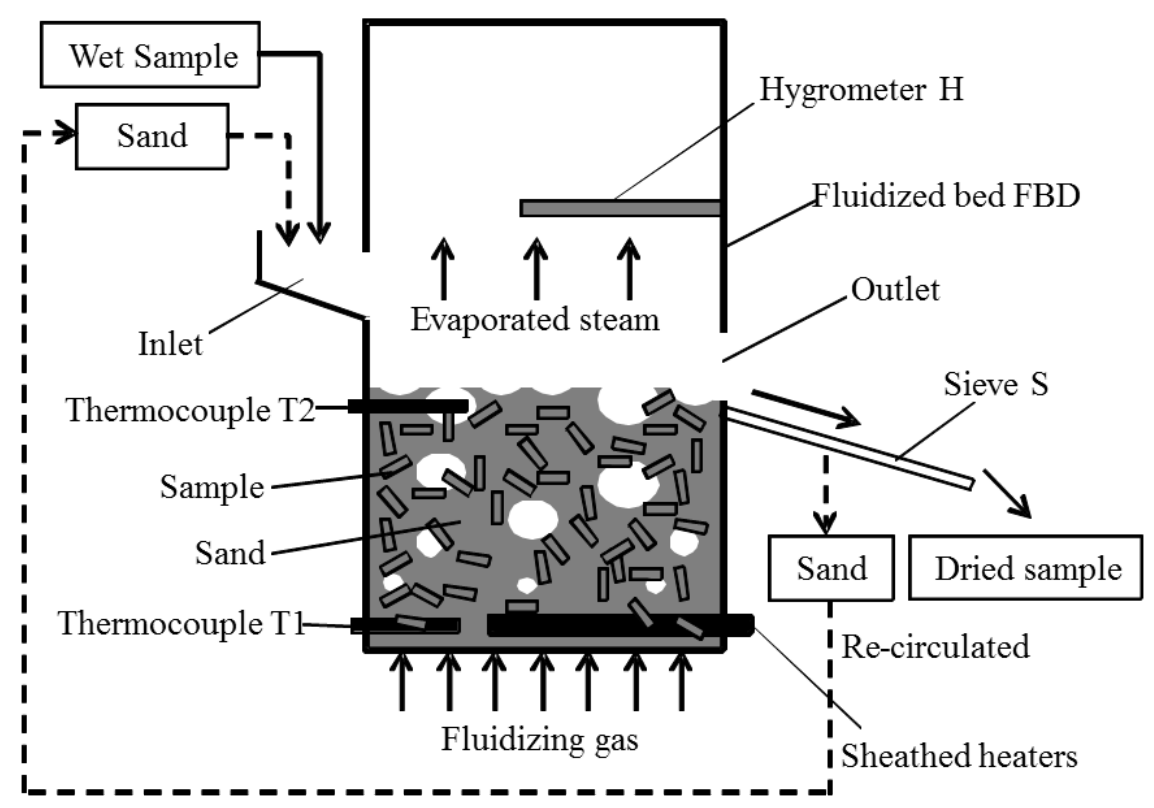


Figure $6 b$

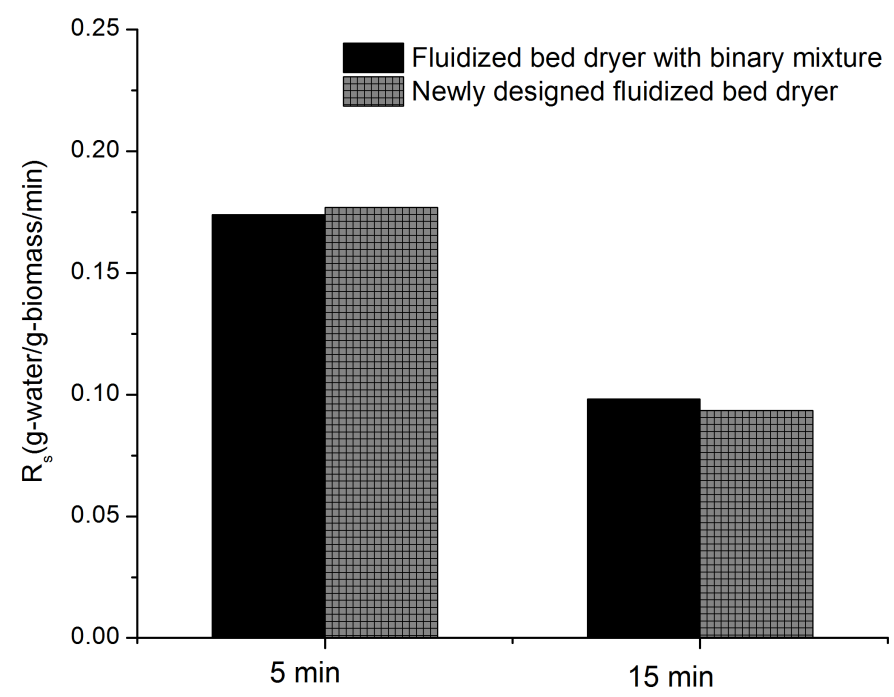

